\title{
ERRATUM
}

\section{A compromise to break the climate impasse}

Marco Grasso and Timmons Roberts

Nature Climate Change 4, 543-549 (2014); published online 8 June 2014; corrected after print 2 October 2014.

In the version of this Perspective originally published, reference 20 contained a typographical error and should have read: Purdon, $\mathrm{M}$. Neoclassical realism and international climate change politics: moral imperative and political constraint in international climate finance. J. Int. Relat. Dev. 17, 301-338 (2014). This error has now been corrected in the HTML and PDF versions of the Perspective. 